\title{
Domestication, Conservation, and Livelihoods: A Case Study of Piper peepuloides Roxb.-An Important Nontimber Forest Product in South Meghalaya, Northeast India
}

\author{
H. Tynsong, ${ }^{1}$ M. Dkhar, ${ }^{2}$ and B. K. Tiwari ${ }^{3}$ \\ ${ }^{1}$ Ministry of Environment and Forest, North Eastern Regional Office, Shillong 793021, Meghalaya, India \\ ${ }^{2}$ Union Christian Collage Umiam, Ri Bhoi, Shillong 793122, Meghalaya, India \\ ${ }^{3}$ Department of Environmental Studies, North-Eastern Hill University, Shillong 793022, Meghalaya, India \\ Correspondence should be addressed to H. Tynsong; herotynsong@yahoo.com
}

Received 8 November 2012; Revised 28 February 2013; Accepted 28 February 2013

Academic Editor: Alexandre Sebbenn

Copyright (C) 2013 H. Tynsong et al. This is an open access article distributed under the Creative Commons Attribution License, which permits unrestricted use, distribution, and reproduction in any medium, provided the original work is properly cited.

\begin{abstract}
Wild pepper (Piper peepuloides Roxb., family: Piperaceae) is an evergreen climber which grows wild in tropical evergreen forests and subtropical evergreen forests of northeast India. This plant grows luxuriantly in the areas with high rainfall at lower elevations ranging from 100 to $800 \mathrm{~m}$ above mean sea level. In Meghalaya, to meet the market demand, farmers have domesticated it in arecanut agroforests and betel leaf agroforests. We found that the mean density of wild pepper in arecanut agroforest is 585 stem/ha and only $85 \mathrm{stem} / \mathrm{ha}$ in natural forest. In India, wild pepper is used in a variety of Ayurvedic medicines. Local people of Meghalaya uses powdered dry seeds mixed with honey and egg yolk for the treatment of severe cough. The study reveals that the average gross annual production of wild pepper is 7 quintals/ha, and final market price fetches Rs. 336,000/ha, out of which $42 \%$ of the money goes to the grower, $16 \%$ to local trader, $23 \%$ to dealer, $17 \%$ to retailer, $1.2 \%$ to wages of labourers, and $0.6 \%$ to transport.
\end{abstract}

\section{Introduction}

People in the rural areas across the world extract a wide variety of nontimber forest products (NTFPs), from nearby forests. NTFPs are important to rural households in terms of their contribution to health, food, energy, and other aspects of rural welfare [1]. In India, an estimated 50 million people living in and around forests rely upon NTFPs for their subsistence and cash income [2]. Bahuguna [3] and Mahapatra et al. [4] have studied at the contribution of NTFPs to cash income; however, such studies are very few, and our understanding of the subject remains inadequate. During recent years, forest managers have begun to consider the role of NTFPs in rural welfare, and in some cases, they have begun to manage forests in a way that promotes outputs other than timber $[5,6]$. What is less understood and represented in policy is the contribution of these extracted products to a household's cash income [4]. When rural households use most of their agricultural output for subsistence consumption, cash from the sale of NTFPs can play an important role by allowing the households to use the same for vital cash-dependent transactions, namely, buying tools and paying for school [1]. It has been assumed that the extraction of NTFPs from natural forests could serve as the goals of biodiversity conservation and poverty alleviation $[7,8]$. It is estimated that roughly $80 \%$ of the developing world including nearly 60 million indigenous people depend on wild fruits, seeds, poles for construction, and medicinal plants to meet subsistence and supplemental income needs [9]. NTFPs play a significant role in providing subsistence and cash income to local populations of the world [10-12]. India's National Forest Policy of 1988 and Joint Forest Management Notification of 1990 reflect the desire and need to ensure that rural people participate in the management of forests and capture benefits from those forests. Such people-oriented forest policy in India will be better implemented and have 


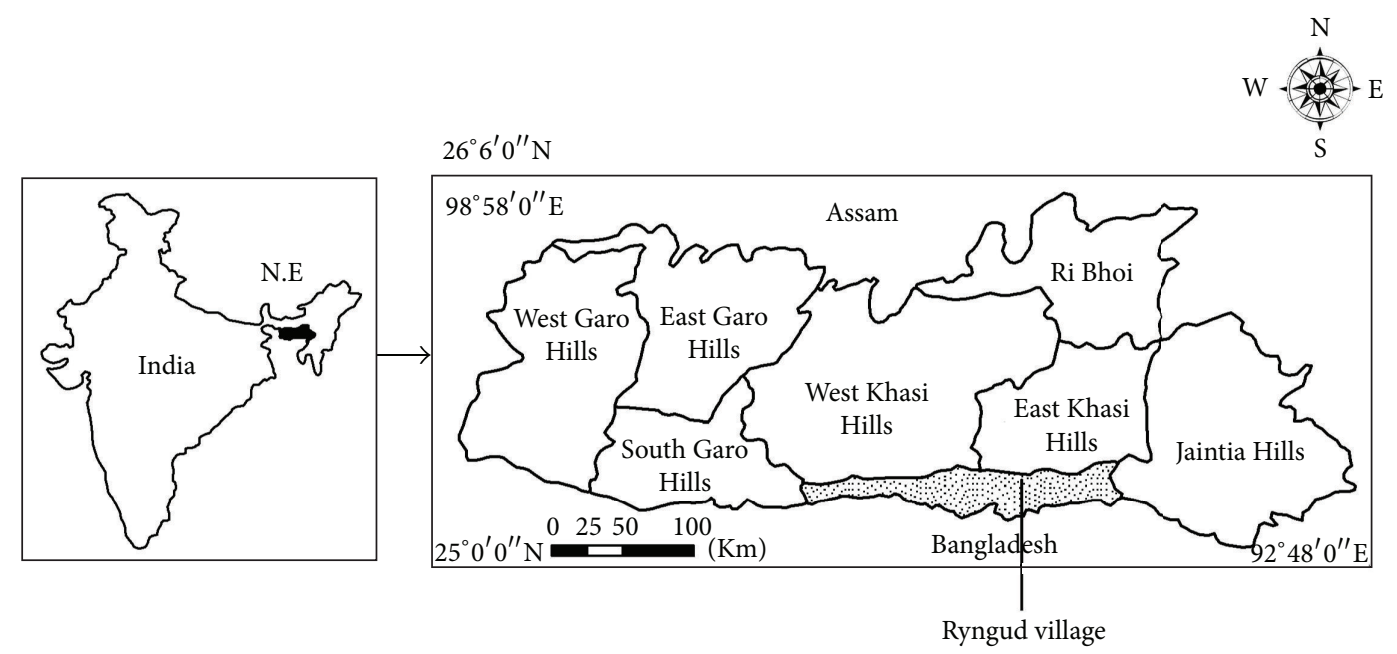

FIGURE 1: Location of the study area.

more impact if more researches on the analyses of NTFPs extraction quantities and values are undertaken across the diverse ecological, economic, and social settings in India. In Meghalaya, about $80 \%$ of the total populations are farmers, and a large section of them cultivates cash crops. Hence, the contribution of forest-based production to cash income of the people is potentially important for understanding the dependency of the rural poor on forests and forest products.

Piper peepuloides Roxb., commonly known as wild pepper, is an evergreen climber belonging to the family Piperaceae. It is found in the forests of Goalpara, North Cachar Hills, and on southern slope of Meghalaya including part of Jaintia Hills, Khasi Hills, and West Khasi Hills districts [13]. The area forms part of Eastern Himalayas, which is recognized for its exceptionally rich biodiversity [14]. In Meghalaya, it grows in areas falling within the altitude range of 100-800 $\mathrm{m}$ above mean sea level. Wild pepper grows wild in the forests and valleys along the streams. However, due to its high market demand, it has also been domesticated in arecanut agroforests as well as in betel leaf agroforests [13]. Seeds are used in a variety of Ayurvedic medicines, a traditional system of medicine known as Ayurveda which originated in India long back in Pre-Vedic period which is believed to be 5000 years BC [15]. Local people of Meghalaya use powdered dry seeds mixed with honey and egg yolk for the treatment of severe cough. There is very little research done on this plant except for the work of Singh [16] who reported that this plant can be used as spice and the research conducted by SFRI [17] on its distribution and medicinal use. In spite of its high market demand, there is little information with respect to habit, economic aspects, conservation, and harvesting and processing. This paper addresses the questions such as management, amount of seed production per plant and per unit area, harvesting, marketing, and its economic impact on the livelihood of the local people.

\section{The Case Study}

This paper is based on a case study conducted in the months of March-May 2008 at Ryngud village of south Meghalaya $\left(25^{\circ} 13^{\prime} \mathrm{N}, 91^{\circ} 46^{\prime} \mathrm{E}\right)$ (Figure 1). The mean annual maximum and minimum temperatures are around $23^{\circ} \mathrm{C}$ and $13^{\circ} \mathrm{C}$, respectively. The mean annual rainfall is $11,565 \mathrm{~mm}$. The slope of the area is predominantly towards the south, and the angle of the slope varies between $10^{\circ}-40^{\circ}$. The area has a large numbers of rivers and rivulets, which drain into the plains of Bangladesh. At times, narrow and deep river valleys separate one hill range from the other. The population density is sparse. Horticulture, forestry, and fisheries are the principal occupation of the people. Agriculture is limited to some small valleys, where mainly tuber crops are grown. Arecanut, orange, betel leaf, jack fruit, bayleaf, honey, and broom grass are the important produce of the region. The area is inhabited by War Khasi people, a tribal community having long tradition of forest conservation. People gather a variety of edibles from forests and water bodies including fish, frog, crustaceans, mollusks, bushmeats, tubers, and wild vegetables. The staple diet of the local inhabitants is rice, fish, and meat. People collect process and market a large variety of nontimber forest products (NTFPs) and medicinal and aromatic plants (MAPs) such as Cinnamomum tamala, Phrynium capitatum, bamboo, honey, mushrooms, nuts, tubers, edible worms, insects, and leafy vegetables from the forests [18].

The natural vegetation of the study area ranges from tropical evergreen to subtropical evergreen forests. The plant species in the forests are distributed in distinct vegetation layers. The important evergreen trees found in South Meghalaya include Cinnamomum tamala, Daphniphyllum himalayense, Myrica esculenta, Sarcosperma griffithi, and Syzygium tetragonum. The deciduous elements included Betula alnoides, Cedrela toona, Engelharitia spicata, and Ficus roxburghii. The shrub layer is thick and is predominantly 
TABLE 1: Summary characteristics of wealth ranks by income and participatory method.

\begin{tabular}{|c|c|c|c|}
\hline \multirow{2}{*}{ Parameter } & \multicolumn{3}{|c|}{ Category } \\
\hline & Rich & Middle & Poor \\
\hline No. of households & 20 & 29 & 73 \\
\hline $\begin{array}{l}\text { Participatory } \\
\text { Wealth } \\
\text { Ranking } \\
\text { Criteria }\end{array}$ & $\begin{array}{l}\text { (i) Large plantations (5-6 } \\
\text { plantations of approx. } 40 \text { ha each) } \\
\text { (ii) Hire labour } \\
\text { (iii) Higher level of cash income } \\
\text { (iv) Houses made of concrete } \\
\text { cement } \\
\text { (v) Good standard of living. }\end{array}$ & $\begin{array}{l}\text { (i) Small plantations }(2-3 \\
\text { plantations of approx. } 40 \text { ha } \\
\text { each) } \\
\text { (ii) Lower level of cash income } \\
\text { (iii) Houses made of wood } \\
\text { covered by tin } \\
\text { (iv) Work as labourers for few } \\
\text { months. }\end{array}$ & $\begin{array}{l}\text { (i) Do not have plantation } \\
\text { (ii) Generally labourers } \\
\text { (iii) Very low level of cash } \\
\text { income } \\
\text { (iv) Houses made of bamboo } \\
\text { covered by straw/tin. }\end{array}$ \\
\hline
\end{tabular}

composed of Ardisia griffithii, Boehmeria malabarica, Goniothalamus sesquipedalis, Mahonia pycnophylla, and Wallichia densiflora. The ground vegetation (herb) is dominated by Borreria pilosa, Commelina benghalensis, Impatiens spp., Ophiorrhiza hispida, Sonerila khasiana, and a large number of ferns. There are a good number of lianas and other climbers seen twining on the trees. The tree trunk and branches are covered with large number of mosses, epiphytic ferns, and different variety of orchids. The invasive weedy species like Artemisia spp., Eupatorium spp., and Mikania micrantha are also present in good number.

\section{Methods}

In this study, four complementary approaches were adopted, namely, (a) formal interview with the village headmen and secretary, (b) field observation, (c) interaction with the head of the selected households through questionnaires, and (d) phytosociological study in natural forests as well as arecanut agroforests [19]. The survey was administered to a random sample of 30 households. The total number of household at Ryngud village is 122 . The production and marketing were studied by using household questionnaires and PRA methods as described by Mukherjee [22]. For understanding the economic value of the wild pepper, data were collected on costs of collection/production, harvesting, processing, value addition, transportation, storage, taxation, and benefit sharing. Marketing analysis was conducted by interviewing growers/local collectors, traders, dealers, and retailers [23]. The marketing channels were investigated using methods described by Raintree [24] and Karki [25]. To study the density and distribution of wild pepper, 40 quadrats $(10 \times$ $10 \mathrm{~m}$ size) were laid in the natural forests as well as 40 quadrats $(10 \times 10 \mathrm{~m}$ size $)$ were laid in the arecanut agroforests. We selected an area of 1 ha in the arecanut agroforests to assess the average production (quantity) and analyze its monetary production in term of per unit area. Table 1 summarizes the characteristics of rich family, middle family, and poor familybased participatory wealth ranking criteria.

\section{Results}

4.1. Management. In Meghalaya, due to its high demand in market, this plant has been domesticated in arecanut agroforests and betel leaf agroforests by using the younger part of the stem tip. It is planted in the month of July and August at the base of trees, by digging the soil and without removing the shrubs and herbs growing in the vicinity of the trees. This is done to prevent wilting of the young stem especially during dry spells. After one month, cultivators do cleaning and lopping of tree branches to help the plant get enough sunlight. These management practices are particularly necessary when the plants are still young. When the plants become old ( $>3$ years), it does not require much weeding and tree lopping. In colder places, fruits are smaller and not as healthy as those which are grown in warmer places. Wild pepper starts producing fruits from the 1st year of cultivation itself, and the production increases from 2nd year onward. No artificial fertilizer was needed for the cultivation of wild pepper. The plants obtain their nutrients from decomposing litter and weeds which people dump at the base of this wild pepper during weeding and tree lopping.

4.2. Density and Production. The mean density of wild pepper plant was found to be $585( \pm 34.43)$ stem/ha in arecanut agroforest and $85( \pm 7.09)$ stem/ha in natural forest. On an average, each plant bears 850-1000 fresh fruits which weighed about $2-4 \mathrm{~kg}$. Based on the household data, it has been found that a total of 143 quintal/annum of dry fruits have been produced by Ryngud village with an average of 1.2 quintal/household. From 1 ha area of wild pepper cultivation, approximately 7 quintals of dry fruits were produced annually.

4.3. Harvesting and Processing. The harvesting of wild pepper starts from the month of March-December. The cultivators pluck the fruits manually by using their finger nail. Plucking usually starts from the ground level by sitting, and then the harvester moves upward by standing and also uses bamboo ladder for plucking fruits that grow at higher level. During harvesting, men, women, and children are all involved. After plucking, the fruits are sun dried for four to five days till they turn light black in color. During drying, care is taken so that it should not be over dried as it will lose its desired black color. Care should also be taken as it should not get wet while drying as it attracts fungus which deteriorates the fruit quality, reducing the profit margin of the cultivators. After 
TABLE 2: Mean annual expenditure $\left(\mathrm{ha}^{-1}\right)$ incurred by the grower towards management, processing, and marketing of wild pepper.

\begin{tabular}{|c|c|c|c|c|}
\hline Activity & Worker & Rate/day (Rs.) & No. of person & Total cost (Rs.) \\
\hline Planting & Men & 150 & 4 & 600 \\
\hline Weeding & Women & 50 & 10 & 500 \\
\hline \multirow{3}{*}{ Harvesting } & Men & 100 & 2 & 200 \\
\hline & Women & 50 & 4 & 200 \\
\hline & Boy & 30 & 4 & 120 \\
\hline \multirow{3}{*}{ Drying } & Men & 100 & 2 & 200 \\
\hline & Women & 50 & 2 & 100 \\
\hline & Boy & 30 & 1 & 30 \\
\hline \multirow{2}{*}{ Sorting } & Women & 50 & 5 & 250 \\
\hline & Boy & 30 & 5 & 150 \\
\hline Packing & Men & 100 & 10 & 1000 \\
\hline \multirow{3}{*}{ Transport from village to road } & Men & $50 \mathrm{p} / \mathrm{kg}$ & - & 350 \\
\hline & Women & & & \\
\hline & Boy & & & \\
\hline Tool & No. & Rate (Rs.) per unit & - & Total cost (Rs.) \\
\hline Gunny bag & 10 & 8 & - & 80 \\
\hline Knife (ka wait) & 2 & 55 & - & 110 \\
\hline Bamboo ladder & 2 & 80 & - & 160 \\
\hline Bamboo basket (ka ruh) & 2 & 50 & - & 100 \\
\hline Grand total & & & & 4,150 \\
\hline
\end{tabular}

Approximate currency conversion 1 USD = Rs. 50 (INR).

drying, the cultivators sort out and discard the fungal infested fruits. Wild pepper has been notified as a forest product, and therefore it attracts royalty and taxes. The traders had to pay the royalty to the District Council. The prevalent rate of royalty was Rs. 100/quintal at the time of study. Alleged illegal collections from the transporters at various check points are also prevalent. The monetary expenditure incurred by the growers towards management, processing, and marketing of wild pepper in 1 ha area is given in Table 2.

4.4. Marketing. The growers usually sell the produce to the local trader at the local market. A small number of growers sell it directly to the dealers in Shillong, which is the largest regional market in the state. The local traders then sell these products to the regional traders also known as dealers. From Shillong, it is transported to other metropolis, namely, Kolkata, Bangalore, Hyderabad, and Chennai via regional traders (wholesalers) based in Guwahati. The dealers sell a small quantity of produce to the retailers in Shillong. The marketing channel of wild pepper is given in Figure 2.

The price and cash flow of wild pepper in the year 2008 is given in Figure 3 . The price is mostly controlled by regional traders (the business men who supply the goods outside the state). These regional traders control the market and are often determining the price at which the growers sell their produce. The growers, however, generally do not have any say in deciding the price. Market demand and price depend upon the quality of fruit and availability of goods. Proper storage was required to protect the product from the attack of fungi. A well-dried and uninfected product fetches best price.

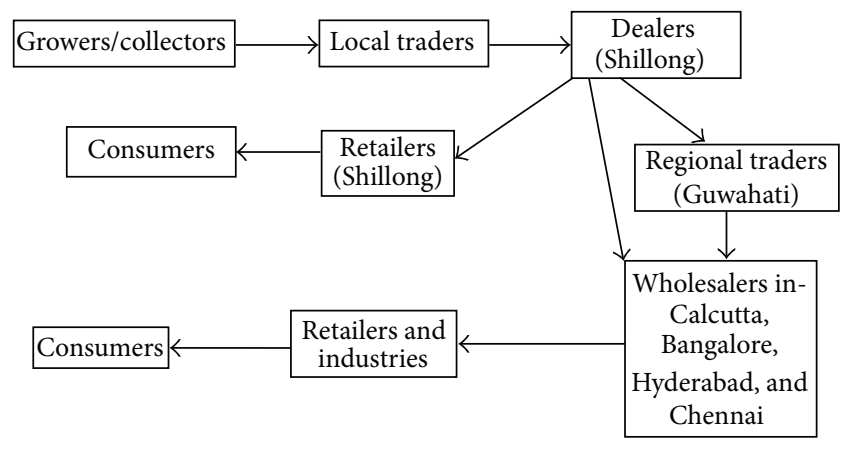

FIGURE 2: Marketing channel of the produce from the grower to the consumer.

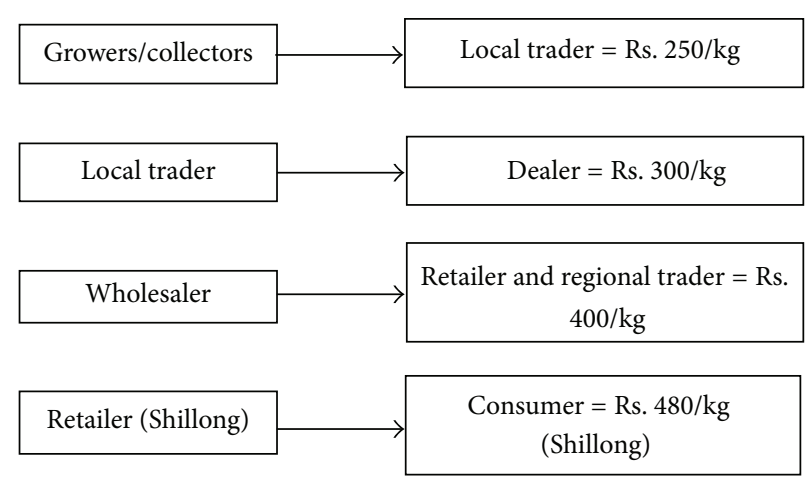

FIGURE 3: Pricing mechanism and average price of wild pepper at various stages of transaction (approximate currency conversion 1 USD = Rs. 50 (INR). 
4.5. Economic Impact. The average gross production of 7 quintals of wild pepper from 1 ha area fetches Rs. 1,75,000/annum (@ Rs. 250/kg), out of which Rs. 4,150 was spent by the growers in management, harvesting, processing, and marketing. Therefore, a grower in Ryngud village annually earns Rs. 1,70,850 $\mathrm{ha}^{-1}$ from the selling of wild pepper. With an average production of 1.2 quintal/household, each household earned an average income amounting to Rs. 30,000 /annum from wild pepper. Based on our household survey, the average annual income at Ryngud village for those households engaged in wild pepper cultivation was found to be Rs. 71,724 . Thus, $42 \%$ of mean annual income of the farmers engaged in wild pepper cultivation and trade came from wild pepper only. However, this value does not reflect the amount earned by every household in the village or area as only the rich and middle class families (40\%) of the village have wild pepper cultivation. The final market price of 7 quintals of wild pepper produced in 1 ha goes to the grower $42 \%$, the rest was shared by local trader $16 \%$, dealer $23 \%$, retailer $17 \%$, wages of labourers $1.2 \%$, and $0.6 \%$ in transport and taxes. The wild pepper market pathway and cost from grower to consumer at the various stages of the movement and processing of the product within the state of Meghalaya is given in Figure 4.

\section{Discussion}

Wild pepper in natural habitats is not the dominant species and thus restricted in its distribution. We recorded that the mean density of wild pepper in natural forest is $85 \mathrm{stem} / \mathrm{ha}$, while in arecanut agroforest, it is 585 stem/ha. Low in its density; results in limited production per unit area that often fail to fulfill market demand. Domestication of wild pepper in arecanut agroforest ensures greater densities and greater production. From the conservation point of view, domestication limits human interference on wild population, thus minimizing disturbance of biodiversity. Murali et al. [26] are of the opinion that NTFP extraction in natural populations even at moderate levels may change floristic composition and erode species diversity and affect population structure. The reason leading to its domestication in Meghalaya is attributed mainly to high market demand, less production in natural forests, and high profit from cultivation.

In term of cash income, the study revealed that $100 \%$ of growers were from rich and middle class families. This is true because in the state of Meghalaya, rich and middle class families have land for cultivations, which the poor families do not have [27]. Therefore, this product can be called as forest product for the rich and middle class families. This is in contrast to Phrynium capitatum, another important NTFPs of Meghalaya in which mostly poor families are involved in collection [19]. The finding of the present study highlighted that cultivation, processing, and marketing of wild pepper are economically viable cropping practices in Meghalaya due to its demand. The value chain has developed and the growers are getting good return to their investments. The trade benefits almost all sections of the society as the landowners benefit from the cultivation, the landless benefit by working

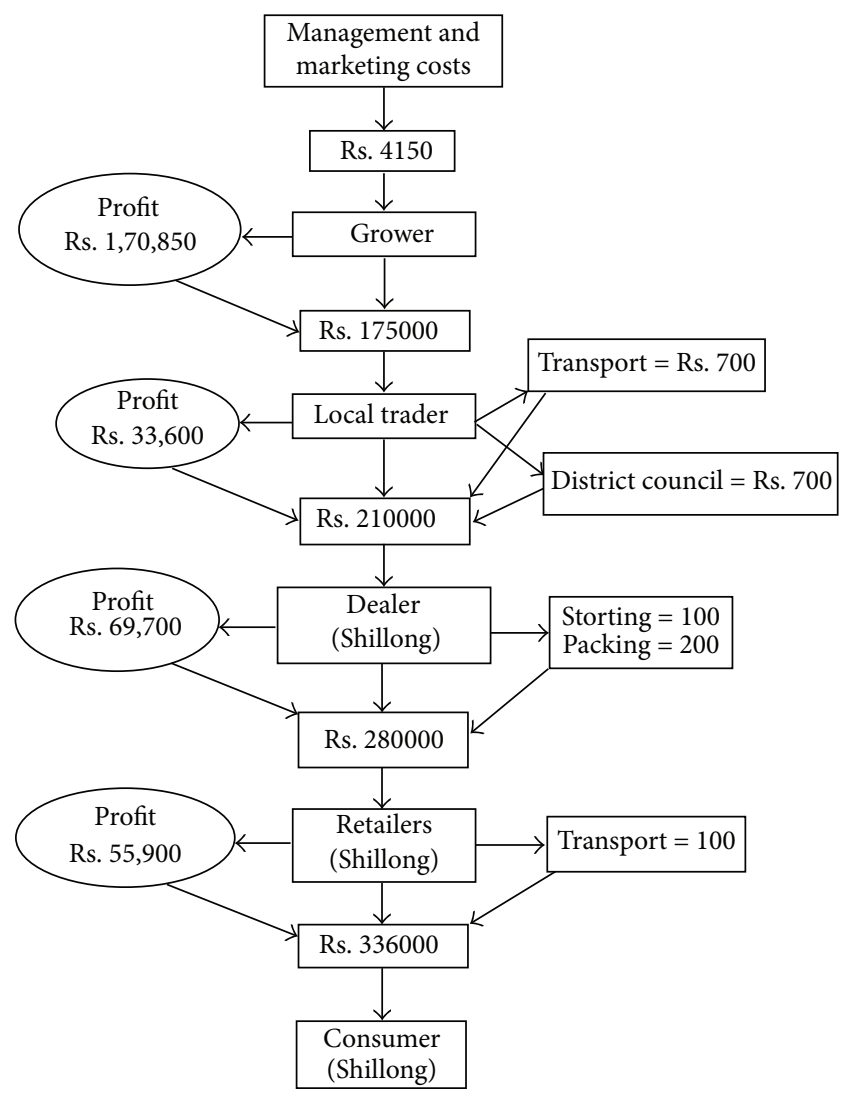

FIGURE 4: Wild pepper market pathway from the grower to the consumer depicting price appreciation at various stages of movement of the product in Meghalaya. For each hectare area of wild pepper, the grower earns a profit of Rs. 1,70,850 and sells to the local trader for Rs. $1,75,000$ who in turn sells it to the dealer who earns a profit of Rs. 69,700 and sell it to the retailer who earns a profit of Rs. 55,900, and the consumer finally have to pay Rs. 3,36,000.

as daily wage labour, and the traders and the transporters earn their livelihood by marketing the produce. The farmers are getting good returns because of low investment and quick and good return as the produce from the plant may be harvested after one year of plantation. In this study a cost-benefit analysis revealed an output/input ratio of 42.16 which is higher than 6.84 obtained from broom grass [16], 3.1 obtained from bayleaf [13], and 1.8 obtained from broom grass [28]. A final value of $42 \%$ accrued to the grower from wild pepper was much better return when compared with the forest produce growers of Solika in Karnataka who received only $4 \%$ of the final value of Phyllanthus emblica fruits [20], War community of south Meghalaya who benefited only 23\% from Bayleaf (Cinnamomum tamala) [13] and 28\% from Phrynium leaf [19], and local people of Darjeeling, Sikkim who received $35 \%$ from the cultivation of broom grass [21] (Table 3).

\section{Conclusion}

The study revealed that domestication and marketing of wild pepper fetche high percent profit to the grower. 
TABLE 3: Comparison of benefits accrued by collectors from different forest products.

\begin{tabular}{lccc}
\hline NTFPs & States & Net benefit of collector (\%) & Reference \\
\hline Piper peepuloides (wild pepper) & Meghalaya & 42 & This study \\
Phrynium capitatum (packing leaf) & Meghalaya & 28 & Tynsong and Tiwari [19] \\
Cinnamomum tamala (bayleaf) & Meghalaya & 23 & Tynsong [13] \\
Phyllanthus emblica (amla) & Karnataka & 4 & Shankar et al. [20] \\
Thysanolaena maxima ( broom grass) & Sikkim & 35 & Shankar et al. [21] \\
\hline
\end{tabular}

The expenditure incurred on the management of wild pepper in agroforest is minimal. It also highlights that domestication of nontimber forest products such as wild pepper could become an effective instrument for rural development and less impact on natural habitat, because its cultivation needs minimum input and labour and generates very attractive economic return.

Wild pepper limited production in the state of Meghalaya may be attributed to the plant limited adaptability, as it requires specific local habitat of slopy nature, high rainfall, and altitudes ranging from 100 to $800 \mathrm{~m}$ above mean sea level. This is the main reason why mass cultivation of this plant is not possible in the state of Meghlaya and also in the entire northeastern region of India. Our findings also highlighted that cultivation, processing, and marketing of wild pepper are economically viable cropping practices only in those area where local habitats are favorable for its growth. The value chain has developed, and the growers are receiving a good return for their investments. The trade benefits almost all sections of society, as the growers benefit from the cultivation, the landless benefit by working as daily wage labour, and the traders and the transporters earn their livelihood by marketing the produce.

\section{Acknowledgments}

The authors are thankful to the Head of Department of Environmental Studies, North-Eastern Hill University, Shillong, for providing necessary laboratories facilities and are also deeply indebted to Dr. (Mrs.) S. J. Phukan, Deputy Director, BSI, Eastern Circle, Shillong, for allowing them to consult the herbaria and deputing her staff to help in the identification of plant specimen. Financial support received from UGCRGNF is gratefully acknowledged.

\section{References}

[1] W. Cavendish, "Empirical regularities in the poverty-environment relationship of rural households: evidence from zimbabwe," World Development, vol. 28, no. 11, pp. 1979-2003, 2000.

[2] D. N. Tewari, Tropical Forestry in India, vol. 387, International Book Distributors, Mumbai, India, 1992.

[3] V. K. Bahuguna, "Forests in the economy of the rural poor: an estimation of the dependency level," Ambio, vol. 29, no. 3, pp. 126-129, 2000.

[4] A. K. Mahapatra, H. J. Albers, and E. J. Z. Robinson, “The impact of NTFP sales on rural households' cash income in India's dry deciduous forest," Environmental Management, vol. 35, no. 3, pp. 258-265, 2005.
[5] A. B. Anderson, Alternative To Deforestation: Steps Towards Sustainable Use of the Amazon Rain Forests, Columbia University Press, New York, NY, USA, 1990.

[6] J. Clay, “A rainforest emporium," Garden, vol. 14, pp. 2-7, 1990.

[7] M. Ros-Tenen, W. Dijkman, and E. Lammerts van Bueren, Commercial and Sustainable Extraction of Non-Timber Forest Products: Towards a Policy and Management Oriented Research Strategy, The Tropenbos Foundation, Wageningen, The Netherlands, 1995.

[8] M. Ruiz Peres, Current Issues in Non-Timber Forest Product Research, CIFOR, Bogor, Indonesia, 1996.

[9] FAO, Global Forest Resources Assessment, http://www.fao.org/ forestry/site/28699/en/, 2005.

[10] B. Belcher, M. Ruíz-Pérez, and R. Achdiawan, "Global patterns and trends in the use and management of commercial NTFPs: implications for livelihoods and conservation," World Development, vol. 33, no. 9, pp. 1435-1452, 2005.

[11] B. Belcher and K. Schreckenberg, "Commercialisation of nontimber forest products: a reality check," Development Policy Review, vol. 25, no. 3, pp. 355-377, 2007.

[12] S. Wunder, "Poverty alleviation and tropical forests-what scope for synergies?" World Development, vol. 29, no. 11, pp. 1817-1833, 2001.

[13] H. Tynsong, Plant diversity and NTFP management in community forests of War area Meghalaya [Ph.D. thesis], North-Eastern Hill University, ShillongIndia, India, 2009.

[14] N. Myers, R. A. Mittermeler, C. G. Mittermeler, G. A. B. Da Fonseca, and J. Kent, "Biodiversity hotspots for conservation priorities," Nature, vol. 403, no. 6772, pp. 853-858, 2000.

[15] B. K. Tiwari, H. Tynsong, and S. Rani, "Medicinal and aromatic plants: medicinal plants and human health," in Encyclopedia of Forest Sciences, J. J. Burley Evans and J. A. Youngquist, Eds., pp. 515-523, Elsevier, Oxford, UK, 2004.

[16] A. K. Singh, "Probable agricultural biodiversity heritage sites in India: VI. The northeastern hills of Nagaland, Manipur, Mizoram, and Tripura," Asian Agri-History, vol. 14, no. 3, pp. 217-243, 2010.

[17] SFRI, State Forest Research Institute Department of Environment and Forests Government of Arunachal Pradesh, Itanagar791 111, Bulletin 2001, 1994-1000.

[18] H. Tynsong and B. K. Tiwari, "Diversity of plant species in arecanut agroforests of south Meghalaya, north-east India," Journal of Forestry Research, vol. 21, no. 3, pp. 281-286, 2010.

[19] H. Tynsong and B. K. Tiwari, "Contribution of Phrynium capitatum Willd. leaf a non-timber forest product to the livelihoods of rural poor of South Meghalaya, North-East India," Indian Journal of Natural Products and Resources, vol. 2, no. 2, pp. 229$235,2011$.

[20] U. Shankar, K. S. Murali, R. Uma Shaanker, K. N. Ganeshaiah, and K. S. Bawa, "Extraction of non-timber forest products in the 
forests of Biligiri Rangan Hills, India. 3. Productivity, extraction and prospects of sustainable harvest of Amla Phyllanthus Emblica, (Euphorbiaceae)," Economic Botany, vol. 50, no. 3, pp. 270-279, 1996.

[21] U. Shankar, S. D. Lama, and K. S. Bawa, "Ecology and economics of domestication of non-timber forest products: an illustration of broomgrass in Darjeeling Himalaya," Journal of Tropical Forest Science, vol. 13, no. 1, pp. 171-191, 2001.

[22] N. Mukherjee, Participatory Methods and Rural Knowledge. Participatory Rural Appraisal Methodology and Applications, Concept Publishing Company, New Delhi, India, 1993.

[23] B. K. Tiwari, "Forest biodiversity management and livelihood enhancing practices of War Khasi of Meghalaya, India," in Himalayan Medicinal and Aromatic Plants, Balancing Use and Conservation, Y. Thomas, M. Karki, K. Gurung, and D. Parajuli, Eds., pp. 240-255, His majesty Government of Nepal Ministry of Forests and Soil Conservation, 2005.

[24] J. Raintree, "Developing and marketing of non-timber forest products: methods used in protected areas in Vietnam," in Shifting Cultivation Towards Sustainability and Resource Conservation in Asia, IFAD, IDRC, CIIFAD, ICRAF, and IIRR, Eds., pp. 269-271, International Institute of Rural Reconstruction Y.C.James Yen Centre, Biga, Silang Cavite, Philippines, 2001.

[25] M. Karki, "Medicinal plants for sustainable management of uplands in south and south-east Asia," in Shifting Cultivation Towards Sustainability and Resource Conservation in Asia, IFAD, IDRC, CIIFAD, ICRAF, and IIRR, Eds., pp. 225-231, International Institute of Rural Reconstruction Y.C.James Yen Centre Biga, Silang Cavite, Philippines, 2001.

[26] K. S. Murali, U. Shankar, R. Uma Shaanker, K. N. Ganeshaiah, and K. S. Bawa, "Extraction of non-timber forest products in the forests of Biligiri Rangan Hills, India. 2. Impact of NTFP extraction on regeneration, population structure, and species composition," Economic Botany, vol. 50, no. 3, pp. 252-269, 1996.

[27] H. Tynsong and B. K. Tiwari, "Contribution of NTFPs to the cash income of War Khasi community of South Meghalaya, North-East India," Forestry Studies in China, vol. 14, no. 1, pp. 47-54, 2012.

[28] A. K. Gangwar and P. S. Ramakrishnan, "Ethnobiological notes on some tribes of arunachal pradesh, northeastern India," Economic Botany, vol. 44, no. 1, pp. 94-105, 1990. 

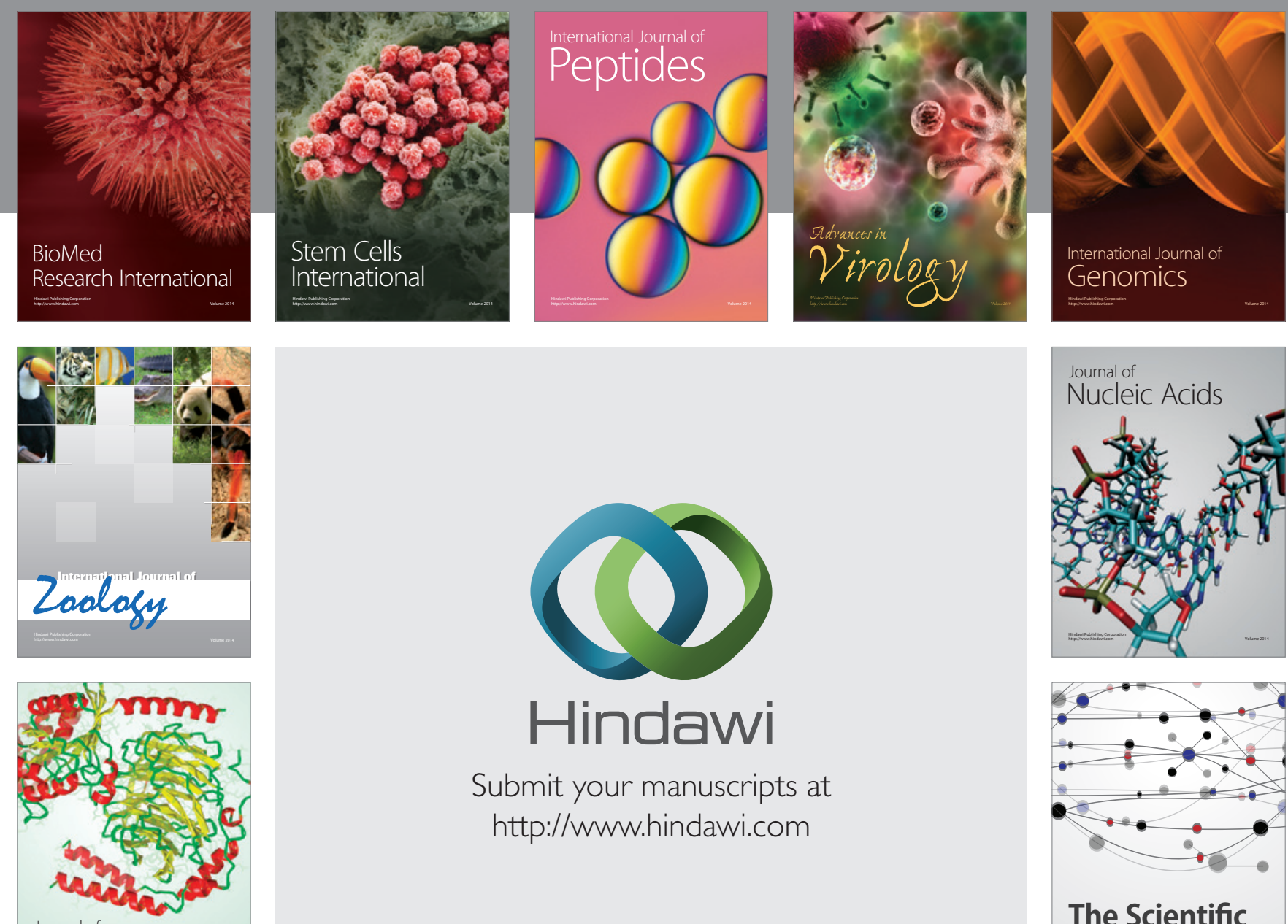

Submit your manuscripts at

http://www.hindawi.com

Journal of
Signal Transduction
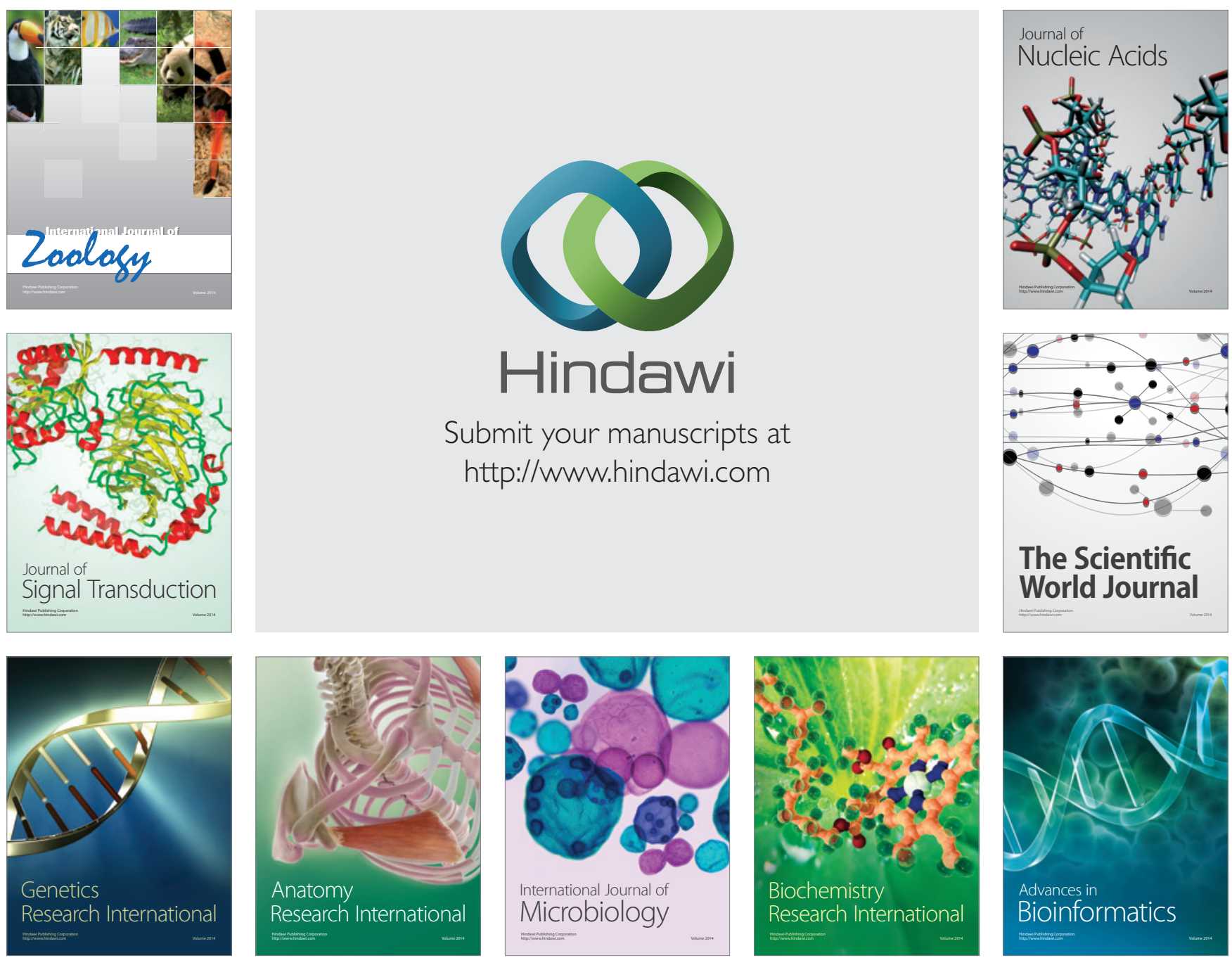

The Scientific World Journal
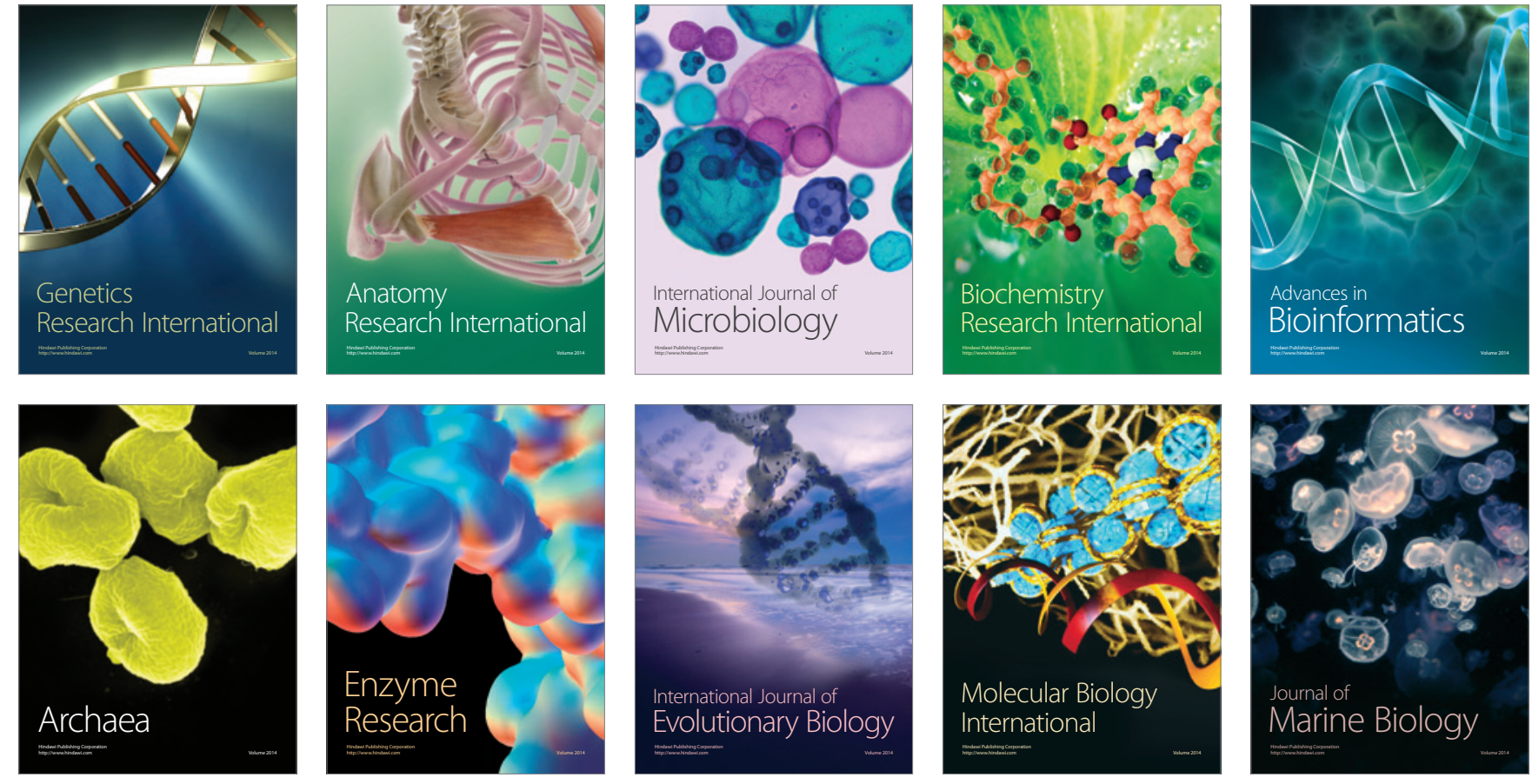